\title{
Transgressive Partnerships: Community engagement in a South African university
}

\author{
Martin Hall
}

\begin{abstract}
Community engagement, along with teaching and research, is one of the three principles of the South African Higher Education system. This role is set out in the 1997 White Paper on Higher Education and has been affirmed as a priority in a series of subsequent policy positions and criteria for quality assurance. The White Paper (which informed the Higher Education Act of the same year) required that public higher education institutions 'demonstrate social responsibility ... and their commitment to the common good by making available expertise and infrastructure for community service programmes'. A key objective was to 'promote and develop social responsibility and awareness amongst students of the role of higher education in social and economic development through community service programmes'. This policy position was reaffirmed three years later in the Ministry of Education's National Plan for Higher Education which asserted the priority of enhancing 'responsiveness to regional and national needs, for academic programmes, research, and community service' (Republic of South Africa 1997; 2001).
\end{abstract}


Yet there has been persistent dissatisfaction with outcomes over the following decade. For example, Lazarus (2007) noted that, while by 1999 most institutions had included the concept of community engagement in their mission statements, only one had operationalized it in the three-year rolling plan required by the Department of Education. Favish argued that concepts of engagement are inadequate because they fail to incorporate fully social, cultural, political and economic dimensions (Favish 2003). Mouton and Wildschut (2007, p. 7), reviewing service learning interventions across a range of institutions, concluded that service learning 'has unfortunately resulted in a strong negative reaction at some institutions ... Institutions are generally reclaiming the contested concept and labelling service-learning with their own terminology or saying that they will do service-learning in their own way'. These observations are supported by the outcomes of institutional audits completed by the Higher Education Quality Committee between 2004 and 2008, which show that universities are at widely varying stages in conceptualizing community engagement practice (Hall 2009a). Singh, summarizing the situation at a landmark conference on aspects of community engagement held in 2006, noted that there is a clear need for a comprehensive reconceptualization and review of community engagement in South Africa's universities (Council on Higher Education 2007).

The articles brought together in this collection contribute to the process of review and reflection through the lens of one higher education institution, the University of Cape Town (UCT). A public univerity, UCT is situated in Cape Town in the Western Cape Province. With South African's second highest population - over 3.5 million - the city, which is the largest conurbation in South Africa, is home to the national parliament and numerous government departments. Founded in 1829, UCT is South Africa's oldest university. As the only university in South Africa listed in the top 200 in the Times Higher Education ranking of world universities, UCT lays claim to being the country's leader in both reseach and teaching (claims that are, of course contested by other universities). While renowned as a centre of liberal opposition to apartheid, UCT now takes a conservative position on scholarship and teaching, tending to 
conceptualize engagement as taking place through the processes of teaching and learning, rather than as a third imperative with its own - distinct - leadership and organizational structures. Broadly, UCT would self-identify with elite institutions in other parts of the world: the Russell Group in Britain, the Group of Eight in Australia, the Ivy League in the USA. This positioning gives a particular perspective to the work of community engagement.

Given UCT's general position that community engagement is best expressed through the practice and scholarship of teaching and research, the strategy that has been developed for taking engagement forward has been to identify and describe cases of good practice through an annual Social Responsiveness Report. These reports, the first of which was launched in 2004, were intended to stimulate debate: firstly, within the university community about different forms of social responsiveness and how learning and research can be enhanced through engagement with external constituencies; and secondly about the role of the university in engaging with the socioeconomic needs especially in a context of deep inequality, and high levels of poverty and unemployment. Case profiles were selected by a Senate working group that took as a key criteria an intentional public purpose or benefit, and engagement with external constituencies. This strategy was successful in that, in 2008, UCT's Senate and Council adopted a policy framework for social responsiveness that acknowledges the interconnectedness between social engagement, research and teaching as well as civic engagement outside the formal curriculum (Favish \& Ngcelwane this volume).

Conceptualizing community engagement as intertwined with teaching and long-established approaches to research leads, in turn, to a consideration of the epistemology of knowledge itself. These are questions about what is accepted as legitimate knowledge, the scope of the university's role in recognizing and validating forms of knowledge and the definition and boundaries of the curriculum, understood as the ways in which the university disseminates knowledge that it has validated as authentic. These issues are further contextualized by the articles that follow, as well as the portraits of good practice in UCT's successive Social Responsiveness Reports, providing an instructive profile of the ways in which a long- 
established and widely recognized university is responding to its location in a country, an immediate hinterland, facing considerable and continuing developmental challenges.

The immediacy of these challenges, and the valency of location, was brought home in May 2008 when South Africa was confronted with an extensive outbreak of racialized public violence directed at economic migrants, refugees and foreign nationals from other parts of Africa. Favish's review of UCT's response to this crisis, seen through the work of a student volunteer organization, a refugee rights project and an academic department, raises key questions of the ways in which immediate humanitarian responses can grow into sustained forms of engagement with underlying issues of poverty, marginalization and racial and national stereotyping. While UCT's response to the crisis showed 'the enormous capacity that exists within universities to contribute to the ongoing development of our society, through research and teaching, as well as through sustained engagement with issues confronting our country', the challenge of sustained engagement remains:

the case profiles suggests that universities need to grapple seriously with the challenge of building the relationships and structural mechanisms that will enable them to enhance their role in promoting the public good. It also raises questions about the critical role of university leadership in universities for developing appropriate strategies for promoting interdisciplinary collaboration and galvanising the intellectual resources of the university to respond to the needs of the majority of people in our country (Favish this volume).

\section{Concepts of KNOWLedge}

A working understanding of community engagement would include service learning, problem-based teaching and research that addresses specific wants and needs, the pursuit of alternative forms of knowledge, and challenges to established authorities that control and direct research systems and the allocation of qualifications. Why has this kind of work remained on the margins of the traditional university in South Africa, despite a decade of clear public policy, and why does there appear to be resistance to its inclusion despite a number of incentives that include moral affirmation for contributing to social and economic justice? 
Articles in this collection show how specific forms of engagement push at the boundaries of conventional knowledge-making. Both Rivett and Tapson and Saldanha show how engagement with key societal issues (respectively, responding to HIV / AIDS and the requirements of workplace education) can unleash potential in both staff and students within the university. McMillan theorizes this as work across institutional borders, a 'boundary zone', arguing that 'we need to shift our unit of analysis ... from individualised practices towards the transaction space or boundary zone and develop conceptual tools to illuminate the complex social practices that occur at this nexus' (McMillan this volume). Favish's overview of UCT's response to the 2008 xenophobia crisis demonstrates how volunteerism, professional fields such as Social Development and advocacy and support projects can be mobilized. London, Heap and Baldwin-Ragaven show how a continuing engagement with human rights issues, originating in the collapse of ethical standards in the apartheid years, has shaped a progressive discourse, 'a shift away from an inward focus on the education of "our" medical students to looking externally to engagement with and linking into social processes in health sciences education'. This, in turn can 'achieve a wider impact on the health sector, consistent with the vision of the Truth and Reconciliation Commission's recommendations for training aimed at changing the culture and practice of health professionals in South Africa' (London, Heap \& Baldwin-Ragaven, this volume).

Sowman's account of the 15-year collaboration between UCT's Environmental Evaluation Unit and the fishing communities of Ebenhaeser (on the Western Cape coast) well illustrates the institutional 'boundary zone' as an area of dynamic opportunity. The Ebenhaeser community first approached UCT in 1993 due to concerns about the presence of diamond recovery vessels in the estuary. This resulted in the initiation of a research project to assess the sustainability of the net-fishery, ascertain the fishers' levels of dependence on the resource and facilitate the development of a co-management system. In turn, this mushroomed into a transdisciplinary research project involving researchers from different disciplines and institutions: 'the fisher community feel an incredible sense of support from their social partners, but realise that it is their knowledge and participation that is ultimately required to ensure that 
their rights are protected ... Researchers and community members now have a common vision and purpose with regard to the research project' and are working together to produce knowledge that can serve community needs and also contribute to scholarship (Sowman this volume).

Do cases such as these, which see the university pushing outwards and embracing new sorts of work change the nature of the university in itself? In order to explore this, we need a way of understanding, and mapping, the epistemology of both traditional and engaged 'knowledge work'. One way of doing this is through Actor-NetworkTheory (Hall 2009b).

There is an extensive literature on Actor-Network-Theory and its use in understanding processes of research. However, for present purposes, Latour's close study of a fieldtrip, comprising a botanist, pedologist and geomorphologist, to study the border of the Amazon forest and the savanna in Brazil, serves well. Latour shows how the research exercise comprises a series of 'transformations'. Thus the research site is mapped, soil samples taken, codified by the use of standards of colour and granularity, removed from the field to the laboratory and published, encouraging further questions that will prompt a return to the field, and the collection and codification of further samples:

knowledge, it seems, does not reside in the face-to-face confrontation of a mind with an object, any more than a reference designates a thing by means of a sentence verified by that thing. On the contrary, at every stage we have recognized a common operator, which belongs to matter at one end, to form at the other, and which is separated from the stage that follows it by a gap that no resemblance could fill. The operators are linked in a series that passes across the difference between things and words, and that redistributes these two obsolete fixtures of the philosophy of language: the earth becomes a cardboard cube, words become paper, colours become numbers, and so forth. An essential property of this chain is that it must remain reversible. The succession of stages must be traceable, allowing for travel in both directions. If the chain is interrupted at any point, it ceases to transport truth - ceases, that is, to produce, to construct, to trace, and to conduct it. The word 'reference' designates the quality of the chain in its entirety ... 
Truth value circulates here like electricity through a wire, so long as this circuit is not interrupted. (Latour 1999, p. 69)

What is particularly useful here is the concept of the 'reference' circulating through a 'circuit' of connected actors to establish and validate an ever-dynamic corpus of knowledge. Further consideration of Sowman's case study of the Ebenhaeser fishing community well illustrates this.

Described in the terminology of Actor-Network-Theory, it is apparent that the Environmental Evaluation Unit's initial facilitation of co-management arrangements established a network that connected UCT, the Ebenhaeser fishing community and the fisheries authority. References circulate in this network as 'understanding and insights into the conditions required for co-management to be operationalised'. Through the university, the network of circulating references is widened to include other countries: 'the notion of comanagement as an alternative approach to managing small-scale fishery systems was being advocated and explored in many countries throughout the world'. As a result, new knowledge is developed: 'the recent proposal to declare a "no-take" Marine Protected Area (MPA) in the estuary has initiated a new wave of research that is focusing on gathering and analysing oral histories from fisherfolk in the Ebenhaeser community'. Political positioning and contested power relationships are fully incorporated as part of the integrated knowledge system: 'the rationale for this research is to gain information on traditional fishing practices and identify customary rules that governed this fishery historically. This information may be required to demonstrate customary rights of these fishers and challenge the proposal to declare a MPA in the estuary'. As a result, there is a common sense of participation in the 'circuit' of references: 'researchers and community members now have a common vision and purpose with regard to the research project' and are working together to produce knowledge that can serve community needs and also contribute to scholarship (all quotations from Sowman this volume).

Using Actor-Network-Theory to understand how communities of practice connect to produce powerful new forms of knowledge further amplifies McMillan's understanding of boundary zones. Her article summarises the work of the Community-Higher Education- 
Service Partnership (CHESP), which has worked to promote service learning in South Africa (McMillan this volume; also Lazarus et al 2008). As with many service learning initiatives, the CHESP programme has challenged the boundedness of the traditional, formal, university curriculum through experiential learning 'in community'. Such 'border pedagogy', when it is successful, results in a joined-up system in which there is a shared understanding of purpose and meaning: 'it is only at the intersection with each other, that these communities of practice become one system and through their activities together, the elements of the system get constituted. The activity system does not exist outside of the service learning activities; the activities act to constitute the system' (McMillan this volume).

In more general terms, the methodology of Actor-Network-Theory and the concept of 'border pedagogy' give substance to the idea of the 'organic intellectual' returning to Gramsci's original conception. Giving effect to this work at, and across, the boundaries of institutions has required the incorporation of different forms and expressions of knowledge in a shared system of circulation. Thus a particular quality of engaged 'knowledge work' that crosses boundaries is that the forms of knowledge that circulate as 'references' vary. This is well illustrated by two cases described by Favish and Ngcelwane in this volume. The portrait of the African Religious Health Assets Programme (ARHAP), located in the Department of Religious Studies at the University of Cape Town, connects practitioners of different forms of knowledge who are concerned in differing ways with the treatment of HIV / AIDS. The shared circuit of communication replaces the sterile distinction between 'academic/ Western' and 'traditional/ African' knowledge with a common way of making meaning in pursuit of a shared set of objectives. Similarly, the portrait of the postgraduate programme in Disability Studies in the Faculty of Health Sciences illustrates how the research community of disabled and non-disabled academics, activists, policy makers and practitioners use participatory and action-oriented research to generate a shared knowledge system for both teaching and policy development (Favish \& Ngcelwane this volume).

A useful way of disaggregating these differing forms of knowledge - or varying forms of 'reference', in the terminology of Actor- 
Network-Theory - is to think of them on a spectrum between highly localized, 'tacit', ways of knowing and universal, 'codified', forms of knowledge (David \& Foray 2003; Foray 2004). Tacit knowledge is localized, developmental and usually communicated by direct interaction. While forms of knowledge transmission such as apprenticeship, learning in the household and oral transmission in initiation processes are standard examples of tacit, or informal, knowledge transmission, so are science laboratories, seminars and the circulation of draft analyses. Codification is essential if knowledge is to be generalized, generally shared and expressed in forms that have explanatory power:

codification consists in translating knowledge into symbolic representations so that it can be stored on a particular medium. This creates new cognitive potentialities that remain inconceivable so long as the knowledge is attached to individual human beings and, hence, only heard (when spoken) or seen (when put into practice) through interaction with those carriers. Inscribing (through writing, graphics, modelling, virtuality) makes it possible to examine and arrange knowledge in different ways and to isolate, classify and combine different components. This leads to the creation of new knowledge objects such as lists, tables, formulae, etc. These are fundamentally important in that they open up new cognitive possibilities (classification, taxonomy, tree networks, simulation) that can provide a framework for the rapid production of new knowledge ... But they are only possible when people consider the matter of recording and, hence, the symbolic representation of their cognitive states. (David \& Foray 2003 p.26)

Recognition of prior learning processes (RPL) are often instances of the alignment of tacit and codified knowledge. Well established as a principle for addressing the acute inequalities of opportunity in South African education, RPL is less often put into practice in ways that enable and empower learners. This may be due to difficulties of translating a person's expertise in tacit forms of knowledge for example, workplace or community expertise, or knowledge gained through forms of apprenticeship - into the codified 'book knowledge' of the academy. The approach taken by UCT's Adult Learners Working Group, described by Saldanha in this volume, 
shows how curricula can be developed that work across established organizational boundaries that separate institutions such as universities, trade unions and government departments. Through the vehicle of a two-year, part-time diploma in adult education, workplace-based educators gain access to the university through recognition of their prior-learning which is often in the form of tacit knowledge. Rather than starting with highly-codified theoretical knowledge, the curriculum opens with reflection on experience, moving iteratively between theory and practice. A key objective is to provide learners with agency to enable them to intervene and facilitate change in workplace contexts, where they will need competence in both codified and tacit forms of knowledge to succeed.

A further example of the potential in bringing both tacit and codified forms into the same knowledge system is again the Ebenhaeser net-fisheries project (Sowman this volume). As with other maritime communities, the Ebenhaeser fishers have an extensive tacit understanding of the ecology of the Olifants River estuary and an appreciation of the probable effects of disruptive interventions, such as the activities of diamond recovery vessels which first prompted them to approach UCT's Environmental Evaluation Unit for assistance. Their perception was that, by linking their close understanding of their circumstances with the EEU's understanding of the scientific basis of estuarine systems and current and pending environmental legislation (codified knowledge par excellence), they could work to secure their livelihoods. From the perspective of the university, the trust established with the Ebenhaeser community opened up a new and valuable source of knowledge that could be codified as reports and academic papers in a number of disciplinary and transdisciplinary areas. This provided university-based knowledge-workers with reputational capital which, for their part as well, further secured their livelihoods (David and Foray 2003). For this combination of tacit and codified knowledge 'references' to work effectively, both Ebenhaeser and UCT participants depend on a common, trusted, 'circuit' through which these ways of knowing can be shared.

\section{THE BENEFITS OF TRANSGRESSIVE PARTNERSHIPS}

By thinking of knowledge in these ways, and relating theory to rich cases of practice, it becomes evident that work across the boundaries 
of institutions results in new and exciting opportunities for creating and distributing new ways of knowing. A first set of benefits is motivational and transformative for the university as an organization. As Favish and Ngcelwane note, case studies show how work began through engagement and activism on key issues that relate to the universitiy's social and political context. They point out that, in theorising the university's role with regard to critical citizenship, work in social responsiveness can lead to an examination of the reconstruction and development functions of higher education, the production of graduates able to promote social justice and construct empowering relationships with disadvantaged communities and the role of higher education in supporting a democratic ethos and cuture of human rights (Favish \& Ngcelwane this volume).

In their account of work in UCT's Faculty of Health Sciences, London, Heap and Baldwin-Ragaven (this volume) show how taking up human rights issues has forced staff to step outside disciplinary boundaries and work with lawyers, adult educators, development practitioners, media experts and political scientists. This has in turn facilitated conceptual development, moving from a narrow notion of human rights as civil and political freedoms, to recognising the increasing importance of engaging with socioeconomic rights challenges in a developing country context and focusing on implementation of human rights principles. Similarly, the Cell-Life project, which facilitates clinical care for HIV positive people, grew from dismay at the Mbeki government's denial of the realities of the AIDS pandemic and the consequent failure to provide vulnerable communities with appropriate health care (Rivett \& Tapson this volume). Turning to adult education, Saldanha (this volume) describes how the field developed in the mid-1980s, at the height of popular mobilisation against the apartheid state and the growth of local civic organizations, providing a space for community and political activists to meet and talk to each other in a way that was quite difficult to do in the face of state repression. The transformative effects of breaking conventional boundaries can result in what Foray (2004) has called a 'combinatorial explosion' - the burst of creativity that can follow from organizing or codifying knowledge in new ways. Naturally, motivational benefits influence the formal domain of the curriculum - the ways in which knowledge is structured for 
development and transmission inside the academy (an important form of codification in itself). The Human Rights focus in the Health Sciences and work in Adult Education each demonstrates this connection. For their part, London, Heap and Baldwin-Ragaven (this volume) describe how redesigned curricula for the health professions have incorporated human rights issues both in classroom teaching and clinical training. And the curriculum for the Diploma in Education (Adult Education) has been developed around critical reflective practice that builds the personal and professional identity of students by recognizing the validity of their prior workplace-based learning (Saldanha, this volume).

One further case also show the benefits of community engagement for curriculum development. Knutsen, Steyn and Nicol (this volume) are concerned with developing knowledge transfer from universities to industry, a key element for economic development and job creation. They point out that there is often a disjuncture between the traditional focus of the university curriculum and the needs of industry, which need short and effective pathways from research and innovation to application. Their case study shows how the finalyear Engineering curriculum can be developed to integrate industry partners in teaching through project development.

It would, of course, be naïve to argue that curricula innovations such as these are self-evident and problem-free. Apart from representing long-established systems of codifying knowledge, the curriculum is often a proxy for access to resources and other 'gatekeeper' functions of the university as an institution, as delineated by Bourdieu in his now-classic study (Bourdieu 1988). Holloway details some of these challenges in her study of the introduction of Disaster Risk Science teaching in the Faculty of Science at UCT. Disaster Risk Science (DRS) incorporates five disciplinary areas - geography, anthropology, sociology, development studies, disaster medicine - and the curriculum also requires a community risk assessment group exercise undertaken over several days in a disaster-prone informal settlement, jointly identified with the City of Cape Town's Disaster Management Centre. This, though, foregrounded well-known tensions in transdisciplinary teaching and research as well as the differing methodologies of the humanities and natural sciences: 'reconciling the tension between 
explicit requirements for internal disciplinary robustness and the transdisciplinary demands of the disaster risk field remains a persistent subtext and institutional challenge .... the experience of the DRS progamme [has been that] although deemed socially and technically valid from the lens of an applied discourse, [it] falls short in conforming to the established disciplinary paramaters of environmental and geographical science It is particularly evidenced by the continued absence of any general operating budget support for DRS teaching and student supervision.' (Holloway this volume).

It will already have been apparent that the 'internal' benefits to the university of these transgressive partnerships have evident benefits to 'external' constituencies, whether these be human rights work, HIV / AIDS interventions, work in adult education, industrial innovation or disaster risk management. Appropriately, the cases in this collection, as well as in UCT's annual Social Responsiveness Reports, emphasise these external benefits as a matter of public accountability. For example, the urban and rural poor, especially those in developing countries, bear disproportionate levels of disaster loss and hardship. New approaches to Disaster Risk Science described by Holloway extend the ability to mitigate such risk by moving from an emphasis on sudden-onset calamities to a focus on pre-existing social and economic vulnerability. This opens up opportunities for improved risk interventions that could reduce the current vulnerability of tens of thousands of people. An appropriate way of calibrating both the 'internal' and 'external' benefits of engaged research and teaching is to ask whether initiatives have resulted in sustainable partnerships between universities and other kinds of organization.

The case studies in this collection include other examples of work with NGOs as well as with other civil society organizations, trade unions and community organizations that work outside both the for-profit private sector and government - a broad category that is becoming known as the 'third sector'. Projects with workplacebased adult educators fall into this category. Those taking part in this programme include community educators from NGOs - early childhood organisations, health and HIV / AIDS organizations - and educators based in trade unions. There are also cohorts from Sector Education and Training Authorities (SETAs) from the Clothing, 
Textile, Footwear and Leather SETA and the Transport SETA. Aspects of the curriculum are negotiated with 'third sector' partners. For example, 'the curriculum for the trade union educators is negotiated with Ditsela - a national trade union education body, to ensure that it is grounded in the trade union context. The course is delivered jointly by the University and Ditsela and is designed and facilitated by staff and educators from the trade unions' (Saldanha this volume).

There is no automatic incompatibility between the ideals of academic freedom and unrestrained enquiry, and teaching and research directed at economic and social development through partnerships. Accordingly, other contributions to this collection are instances of productive partnerships with industry and with the state sector. The potential for a sustainable relationship with forprofit industry is set out in Knutsen, Steyn and Nicol's case study of materials and manufacturing. This initiative is grounded in South Africa's National System of Innovation, introduced in 1996 as a strategy to enhance international competitiveness and create new jobs. The Cape Initiative in Materials and Manufacturing (CIMM) was formed to advance materials science through industry-university partnerships. CIMM aims to give companies access to affordable research and development and to extend research interaction at postgraduate level. Because there are evident benefits to both sides of the partnership, this initiative is seen as sustainable through addressing clear sets of interest.

A good example of a partnership with the state sector is the work of UCT's Cell-Life project, in conjunction with the Desmond Tutu HIV Centre in the Faculty of Health Sciences. The Centre had developed a treatment management method, using HIV+ community members who had successfully started their antiretroviral treatment programme (ART) as treatment advocates. Cell-Life contributed an information technology system, based on cellular communication, that alleviated patient overload as the treatment management system expanded. This system called Intelligent Dispensing of ART (iDART), was specifically designed for anti-retroviral dispensing in the state public health care sector. Conventional clinics, with one pharmacist and using a paper-based system, can dispense to approximately 80 patients per day, which results in a treatment ceiling of approximately 2000 patients for that clinic. The alternative model developed by 
the Desmond Tutu HIV Centre and Cell-Life uses a pharmacist in a central location who dispenses medication, which is then sent in sealed packages to the clinic where the patient is able to collect the medication from a pharmacy assistant. iDART was designed to integrate such pre-packing, or down-referral, models. It is today installed in more than 30 clinics across South Africa and supports the dispensing to nearly 70,000 patients on a monthly basis (Rivett \& Tapson this volume).

\section{ConcLusion}

Taken together, the profiles of practice in this collection provide an overview of a university community working to adapt the traditional goals of teaching and research to a scholarship of engagement with key social and economic activities. While working in a range of fields these practitioners share the conviction that the work of the university cannot be detached from its social and economic context. In this sense, all are Gramscian organic intellectuals.

Reading through cases such as these throws light on the broader questions of higher education policy with which this introductory article opened. It can now be seen that the gap between policy and practice from the publication of the 1997 White Paper to the present results in part from a confused and incomplete theorization of the ways in which new knowledge is constructed. By using the device of Actor-Network-Theory, and concepts such as tacit and codified knowledge, it can be seen how work at, and across, institutional boundaries works, and the opportunities and barriers that such transgressive enterprises entail. In particular, it becomes clear that there is no inherent reason why knowledge claims, or assertions of authenticity or validation, should be restricted to the university as an institutional form. There is no principled reason why tacit and localized knowledge originating outside the university should remain uncodified and therefore of low general utility, or why knowledge originating outside of its bastions should be of any particular threat to the continued existence of the university as an institution. Indeed, the opposite can be argued: unless the university participates in these broad, inter-institutional networks, it is likely to be marginalized.

Looking to the future, and mindful of the need for reconceptualization that was emphasized at the 2006 conference 
on community engagement and higher education in South Africa, one way forward is to think in terms of the distinction between private benefits and public goods. Higher Education clearly benefits individuals, who gain qualifications which provide them with access to high status employment and, on average, higher lifetime earning than those without tertiary education. Universities also offer a range of private benefits to the corporate sector through industry-sponsored research, outputs in journals and books that provide commercial publishers with profits, and licences and patents that constitute intellectual property that may yield a financial return for its owners. At the same time, universities clearly benefit the public, both as individuals and collectively, through providing access to education, raising national competitiveness through skilling the workforce and fuelling regional and national economic growth, combating poverty, marginalization and unemployment. By means of the principles of institutional autonomy and academic freedom, universities are part of the democratic process, generating critique of centres of economic and political power and, hopefully, educating a critical citizenry.

From this perspective, what is understood and implied in the concept of community engagement can be understood as a part of a set of public goods emanating from higher education. This approach allows the objectives of community engagement to be understood within their context. For South Africa, responding to the imperatives of the public good would include addressing the challenges and issues raised in each of the case studies in this collection. For a university such as UCT, focusing on the imperatives of the public good would address the question raised by student leaders Wendy Lewis and Thandi de Wit in reflecting on their engagement with the humanitarian crisis that engulfed Cape Town in the winter of 2008:

in ten years time, if something like this hit again, we would have doctors, lawyers, biologists, engineers, business people, musicians, sociologists, playwrights etc. all knowing a little more about how to respond to this situation, and wanting to respond to the situation, because they know that it is each individual that counts, not just the name of an institution. (Favish this volume) 


\section{REFERENCES}

Bourdieu, P 1988, Homo academicus, Stanford University Press., Palo Alto Ca.

Council on Higher Education 2006, Community engagement in higher education: Proceedings of the conference, Council on Higher Education, Pretoria.

David, P \& Foray D 2003, 'Economic fundamentals of the knowledge society;' Policy Futures in Education vol. 1, no.1, pp. 20-49.

Favish, J 2003, Monitoring the quality of higher education: The case for making contributions to development central to considerations of quality, International Conference on Assessing Quality in Higher Education, Cape Town.

Foray, D 2004, The economics of knowledge, MIT Press, Cambridge.

Hall, M 2009a, Community engagement and the higher education system in South Africa: A metaanalysis: Report to the HEQC, Council on Higher Education, Pretoria.

Hall, M 2009b, 'New knowledge and the university'. Anthropology Southern Africa, vol. 32, nos. $1 \& 2$, pp. $69-86$.

Latour, B 1999, Pandora's hope: Essays on the reality of science studies, Harvard University Press, Cambridge.

Lazarus, J 2007, 'Embedding service learning in South African higher education: The catalytic role of the CHESP initiative', Education as Change vol. 11, no. 3, pp. 91-108.

Lazarus, J, Erasmus, M, Hendricks, D, Nduna J \& Slamat, J 2008, 'Embedding community engagement in South African higher education', Education, Citizenship and Social Justice, vol. 3, no. 1, pp. 57-83.

Mouton, J \& Wildschut, L 2007, 'An impact assessment of the CHESP initiative: high-level findings', JET Education Services, Johansbur

Republic of South Africa 1997, 'A programme for the transformation of higher education (White Paper 3)', Government Gazette, 18207.

Republic of South Africa 2001, National plan for higher education, Ministry of Education, Pretoria. 